carum," fascicule vi. ; M. Kamenski's "Comparative Researches into the Development and Structure of Urticularia ;" and several botanical papers published in Russian scientific periodicals.

THE additions to the Zoological Society's Gardens during the past week include two White-eared Bulbuls (Pycnonotus leucotis) from North-West India, presented by General W. H. Breton; a Magpie (Pica rustica), British, presented by Mr. H. Stacy Marks, R.A., F.Z.S.; two Turtle Doves (Turtur communis), British, presented by Mr. N. Brooks; a Daubenton's Curassow (Crax daubentoni) from Venezuela, presented by Capt. Rigaud, s.s. Larne; a Loggerhead Turtle (Thalassochelys caouana) from the Atlantic Ocean, presented by Mr. R. T. Ward; two Green Lizards (Lacerta viridis); two Marbled Newts (Molge marmorata), European, presented by the Rev. F. W. Haines; a Crested Pigeon (Ocyphaps lophotes) from Australia; a Secretary Vulture (Serpentarius reptilivorus) from South Africa; an Elliot's Pheasant (Phasianus ellioti of); a Temminck's Tragopan (Ceriornis temmincki o) fro:n China ; four Spotted Tinamous (Nothura maculosa) from Buenos Ayres; two Indian Crocodiles (Crocodilus palustris) from India, deposited; eight Ocellated Sand Skinks (Seps ocellatus) from Malta, purchased ; a Bennett's Wallaby (Halmaturus bennetti of) born in the Gardens ; a Common Crowned Pigeon (Goura coronata), a Cockateel (Calopsitta nova-hollandia) bred in the Gardens.

\section{ASTRONOMICAL PHENOMENA FOR THE WEEK I887 AUGUST 7-I3.}

(FOR the reckoning of time the civil day, commencing at Greenwich mean midnight, counting the hours on to 24 , is here employed.)

\section{At Greenwich on August 7}

Sun rises, 4 h. $35 \mathrm{~m}$. ; souths, $12 \mathrm{~h} .5 \mathrm{~m} .33 .8 \mathrm{~s}$. ; sets, $19 \mathrm{~h} .36 \mathrm{~m}$. ; decl. on meridian, $16^{\circ} 27^{\prime}$ N. : Sidereal Time at Sunset, I6h. $40 \mathrm{~m}$.

Moon (at Last Quarter on August II) rises, 20h. $58 \mathrm{~m} .{ }^{*}$; souths, 2h. $29 \mathrm{~m}$. ; sets, 8 h. $9 \mathrm{~m}$. ; decl. on meridian, $6^{\circ} 14^{\prime} \mathrm{S}$.

\begin{tabular}{|c|c|c|c|c|c|c|c|c|}
\hline Planet. & & $\begin{array}{l}\text { Rises. } \\
\text { h. m. }\end{array}$ & & $\begin{array}{l}\text { Sou } \\
\text { h. }\end{array}$ & $\begin{array}{l}\text { thss. } \\
\text { m. }\end{array}$ & & $\begin{array}{c}\text { Sets. } \\
\text { h. m. m. }\end{array}$ & Decl. on meridia \\
\hline Mercury & $\cdots$ & 336 & $\cdots$ & II & 7 & $\cdots$ & I8 38 & $163 \mathrm{I}$ \\
\hline Venus ... & $\ldots$ & 844 & $\ldots$ & I4 & 42 & $\ldots$ & 2040 & $\ldots$ \\
\hline Mars ... & $\cdots$ & I 59 & $\cdots$ & 10 & I3 & $\cdots$ & 1827 & $\ldots$ \\
\hline Jupiter... & $\cdots$ & II 32 & $\cdots$ & 16 & 45 & $\cdots$ & 2158 & Io $3 \mathrm{~S}$. \\
\hline $\begin{array}{r}\text { Saturn... } \\
* \mathrm{I}_{\mathrm{n}}\end{array}$ & $\begin{array}{l}\ldots \\
\text { dicate }\end{array}$ & $\begin{array}{l}3 \quad 3 \\
\text { es that th }\end{array}$ & a. risi & $\begin{array}{l}\text { I I } \\
\text { ng is }\end{array}$ & $\begin{array}{c}0 \\
\text { that }\end{array}$ & $\ldots$ & $\begin{array}{l}\text { I } 857 \\
\text { e precedir }\end{array}$ & $\ldots \quad 2037 \mathrm{~N}$. \\
\hline
\end{tabular}

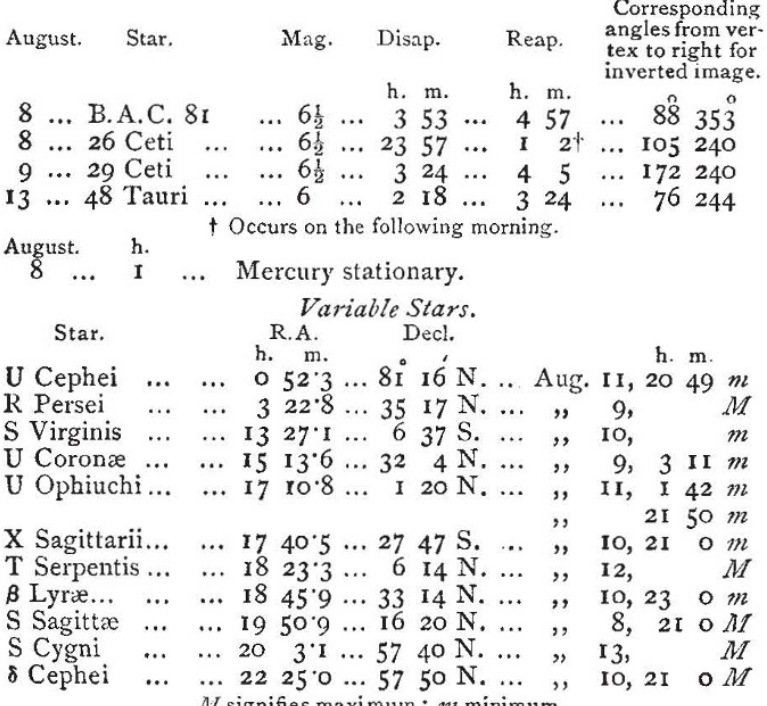

Meteor-Showers.

The present season is generally the richest in the year for meteors, being the season of the Perseids, and the neighbouring showers.

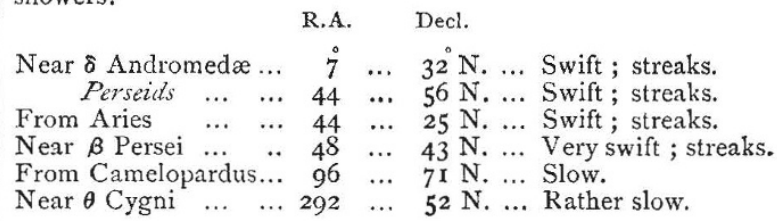

\section{THE JUBILEE OF THE ELECTRIC} TELEGRAPH.

$\mathrm{N}^{\mathrm{N}}$ December $\mathbf{1 2}, \mathbf{1} 837$, William Fothergill Cooke, on behalf of himself and Charles Wheatstone, set his hand and seal to Patent No. 7390, the subject of the specification being: "Certain apparatus or mechanism which is constructed according to our said improvements for giving signals and sounding alarums in distant places by means of electric currents transmitted through metallic circuits." This, the first English patent dealing with the electric telegraph, contains the elements of a thoronghly practical apparatus, as the historical experiment of July 25, 1837, made between Euston and Camden Town, had proved. Unlike many other developments of practical science, the commencement of the epoch when electric telegraphy became a practical success in this country can be sharply defined, and what will become an historical event, viz the commemoration of July 27,1887 , can strictly be said to be the true jubilee of the electric telegraph.

To say that the invention of which Cooke and Wheatstone were the pioncers has done more to transform the conditions of human existence than any other except the steam-engine, and some would add "gunpowder," is but to restate an acknowledged fact. The electric telegraph has so changed the conditions of our social existence as to become indispensable to the same, and we could almost as soon do without food and clothing as dispense with the power that has annihilated distance. The evolution of the electric telegraph as a means of transmitting intelligence from a distance did not, of course, commence from the year when Her Majesty began her reign. The names of Konald, Schilling, Watson, Sömmering, Schweigger, Weber, Lesage, and very many others, will at once occur to those who give a moment's thought to the subject, as workers in the field long before Wheatstone made his famous experiment, but few, we think, will question the assertion that electric telegraphy as a commercial success distinctly dates from the year 1837 .

The commemorative dinner was held in the Venetian Hall at the Holborn Restaurant on W'ednesday evening, July 27, the Right Hon. H. C. Railes, M.P., the Postmaster-General, being in the chair. A large number of representative men were present (the company mustering about 250 ), though during the last ten years or so death has sadly thinned the ranks of the "old hands," of the Electric, U.K. and Magnetic Companies. Amongst the men of science and others who attended were Capt. Fonseca Varz, Mr. S. W. Silver, Dr. J. H. Gladstone, Mr. C. B. Bruce, the Marquis of Tweeddale, Mr. William Crookes, F.R.S., Mr. Edward Graves, Prof. W. G. Adams, M. Caël, Mr. Jacob Brett, Mr. H. Weaver, Mr. John Pender, Mr. C. H. B. Patey, Mr. G. Shaw-Lefevre, M.P., Lord Onslow, Prof. Stokes, Sir Lyon Playfair, M.P., Sir William Thomson, Sir Frederick Goldsmid, Sir Frederick Abel, Sir Douglas Galton, Mr. J. C. MacDonald, Mr. Edwin Clark, Sir David Salomons, Sir George Elliott, Colonel Andrews, R.A., Mr. Matthew Gray, Sir James Anderson, Mr. Norman Lockyer, Mr. H. C. Fischer, Prof. Hughes, Mr. W. H. Preece, Sir C. Bright, Major-General Webber, Mr. C. E. Spagnoletti, and Mr. Latimer Clark. Letters expressing regret at non-attendance were received from the Marquis of Salisbury, Lo:d John Manners, Viscount Cross, Mr. W. H. Smith, Sir H. Hoiland, Sir W. Grove, Sir D. Gooch, Sir A. Borthwick, M.P., Dr. von Stephan (Berlin), Dr. William Siemens (Berlin), Mr. Cracknell (Sydney), Mr. C. Todd (Adelaide), and others.

The Chairman having proposed the usual loyal toasts, proposed the toast, "To the Memory of the Pioneers of Telegraphy," asking the company to join in an expression of 
reverence for those great and illustrious men who have ceased to be among us, by drinling the same in solemn silence.

The Chairman then said :-We have most of us perhaps read of that tumultuous sensation which the great Wheatstone confesses to have experienced when the message which he sent on that little journey from Euston Square to Camden Town was sent back to him by Mr. Cooke. I am perhaps not exaggerating the importance of that occasion when I venture to say that that evening as Wheatstone sat in the small cupboard of an office communicating with his colleague at a distance of some two miles, was one of the great epochs in the history of human progress and if ever a spirit of prophecy has filled a man with something of a divine enthusiasm, it may well be that the man with whose name the system of the electric telegraph must ever be in separably connected, may have felt his heart throb with something almost supernatural when he realized that the great work had been achieved, that the demonstration had been reached, and that the future of the science was assured. I venture to believe that when we look back upon the progress of those fifty years, we shall find in them the materials for a greate hupe of the future of humanity than in almost any other record of any other period in the history of our race. I would remind you that the instrument which was employed by Wheatstone and Cooke displayed five needles, and that it was from the movements and combinations of those five needles that the whole of the alphabet was made up. Those five needles, we are told, were united by means of five copper wires laid in a groove in a triangular block of wood, and I am sure you will be interested to know that a piece of that block is in my hand at the present time, and well deserves to be preserved among the archives of science. Well of cotrse we are with the experience of this half century well aware that this system in the first instance was cride and imperfect. Demonstrations had been arrived at, but perfection had to be reached. The difficulty that was immediately encountered in popularizing the system was obvinted by the development of the railway enterprise of this country and the necessity which arose for rapid and certain communication along our lines of rail way. However, some time elapsed before the real development of telegraphy in this country began. The London and Blackwall Railway was, I believe, the first to utilize the system in a practical way. In I 844 the Government of Sir Robert Peel were the first to realize how far the telegraph might be applied to the service of the State; and that year saw the establishment of a telegraph line from Waterloo to Gosport, and that I think you may say constituted the first public recognition of the value of the electric telegraph. In I846 the first telegraph company was formed-the Electric Telegraph Company. In I850 the first attempt was made to lay a submarine telegraph cable. A guttapercha wire, without any metallic covering, was laid between Dover and Calais in August of that year, and you will be interested to know that $I$ have also here a portion of that cable, which was fished up by a ship in the Channel so recently as the year 1875 . In 1851 a cable was laid in substitution of this gutta-percha cable, which was protected by iron wires, and which was the commencement of a regular system of inter-communication between England and the Continent, and this cable I believe I am not wrong in associating with the name of one of those gentlemen who is happily still spared to be among us-I mean $\mathrm{Mr}$. Crampton-and it must indeed be a great satisfaction to anyone who has been connected with great works of this sort to have lived, as Mr. Crampton has done, to witness their enormous development in the service of mankind. The first Atlantic cable was laid in 1858 , and other companies arose during those years to compete with the first electric telegraph company, ard multiplied throughout the length and breadth of England the agency of the telegraph. In 1870 the multiplication of the companies had become so great that their competition, though in some respects advantageous to the public, was yet so imperfectly regulated by State requirements, that the Government of the day determined to acquire the whole of their enterprises, and to place the telegraphs of the Kingdom under the direction of the Post Office. Now, I should like to say one or two words with regard to the instruments of telegraphy. We are aware that the first telegraphic apparatus employed by Wheatstone and Cooke was one which required five wires through which to transmit their message. It was found gradually that two wires would suffice to forward a message, and after that the progress of science enabled the operaters to depend upon one. But after a time it became ascertained that a wire could be used for sending mes:ages in two directions, and after that time four messages came to be trans- mitted on a single wire, two in cither direction; and, as I dare say most gentlemen who are present to-night are aware, at the present time a single wire is being used at the central telegraph station in such a manner as to admit of six messages being sent in one direction, or one in one direction and five in the other, or any other combination of six messages. The first five-needle iustrument was succeeded by the double needle, and the double needle by the single needle ; all those systems were visual. Then came in the system of printing on a hand of paper. At first the signs representing the letters were embossed on the band. This was further improved by Prof. Iughes's printing instrument, by which the actual letters were printed in ink. Then came yet another--the sounder instrument, by which messages are trans. mitted by sound without any record. With regard to speed, when the first electric telegraph was established the speed of transmission was from four to five words a minute on the fiveneedle instruments. In 1849 the averagc rate of transmission of a certain number of messages addressed to the Times newspaper was $I 7$ words a minute. The present pace of the electric telegraph between London and Dublin, where the Wheatstone automatic instrument is employed, amounts to 462 words a minute, and thus what was regarded as miraculous fifty years ago, has multiplied a hundredfold in the course of one half century. Now you may perhaps like to know, though it is rather descending from the higher walk of this great subject, the number of telegrams which were sent through the Post Office in the United Kingdom last year. The number was $5 \mathbf{I}, 500,000$; that is nearly $1,000,000$ per week, and that number is still steadily increasing. $4 \mathrm{I}, 000,000$, or rather more than that number, of these were inland messages, and of course a very great proportion of them were Press messages. I think you should realize the immense boon which the electric telegraph has bestowed upon the Press. I gather from such information as I have been able to obtain that the rate for Press messages, which as everybody is aware is very much less than the rate for other messages, is on the average not much more than $2 d$. per roo words; and it is owing to these extraordinary facilities, afforded by the Post Office to the transmission of Press news, that the whole of the United Kingdom is put in possession at its breakfast table every morning of everything which it is necessary or important for anybody to know, as well as of a great many things which are neither necessary nor important. I I believe that I am not wrong in sayin that the cost to the public revenue of this reduced rate to the Press is not less than $£ 200,000$ a year, and that the newspapers of this country practically receive a subsidy of $£ 200,000$ a year in order to enable them to assist in the diffusion of intelligence. I imagine that the country is well satisfied that this should be so, and that there are very few people who would wish to abridge that privilege, having regard to the enormous importance to all classes of the community of being placed at the earliest moment in possession of the fullest knowledge of what is going on. But it is a fact that, owing to the recent reduction in the tarift of telegrams, the value of the telegram on the average to the State is now only $8 d$., whereas two years ago it was $\mathrm{I} s . \mathbf{1} \boldsymbol{d}$.; and before the State took over the telegraphs it amounted to as much as $2 s$. $2 d$. I think you may measure something of the enormous gain which the public has achieved by the acquisition by the State of the telegraph system when you look at these figures and reflect that the average price of a telegram at the present time is only about a third of what it was only seventeen years ago. I am saying this as if I were one of the public; but as Postmaster-General you must be aware that I have to regard this result with somewhat mixed feelings, and I am endeavouring, as far as I can, to denude myself of any official prepossession in putting before you from the popular side the advantages which you have obtained by the State employment of the telegraphs. I would add that if you would wish to obtain further knowledge of this most interesting subject, put in the most terse and pregnant way, you cannot do better than study a paper communicated to the Society of Arts by my friend Mr. Preece. The great agency of telegraphy which seems to form the vital principle of this planet upon which we live, this great agency which has not only gone so far towards annihilating space, but which seems at the present time to be regenerating light and revolutionizing motion, has all the future before it. Those who are enrolled in its service are probably the disciples and the apostles of a new and absolutely beneficial dispensation, and with them rests the future, in no small degree, of the human race, and the means of linking not merely ourselves to our distant colonies--and my noble friend who is beside me (Lord Onslow) 
reminds me how important is the connexion between England and the younger Englands beyond the sea-but by going forward in connecting the various races of mankind by binding island to island and continent to continent. The telegraph is doing in its own quiet, its own noiseless, and its own unobtrusive way, more than all the noisiest missionaries of peace and universal brotherhood have ever accomplished.

Mr. Edwin Clark, in acknowledging the toast on behalf of "The Past," described the origin of the Electric Telegraph Company, in the organization of which he took a prominent part, the difficulties he had to encounter in curtailing expenditure, and in putting into a thoroughly sound state the wires and the system of insulation which then prevailed. He pointed out that the railway companies were really in its early stages the greatest benefactors of the telegraph. He had been deputed to examine the telegraph system prevalent in Europe in those early years in connexion with the railways, and he had recommended what had now become universal on the railway system of this country - the block system.

Mr. John Pender, on behalf of "The Present," said :-My mission to-night is to tell you what submarine telegraphy has done. I am one of those few commercial men who at an early period of telegraphy saw that there was in it the promise of a beneficent instrument for the future progress of the world. have gone into submarine telegraphy, not as an expert, but as one of those who have come forward and taken science by the hand, and led it up to the glorious results which we have seen. Twenty years ago there was only something like 2000 miles of submarine cables; now there are II 5,000 miles; and it has cost something like $£ 38,000,000$ or $£ 39,000,000$ sterling to put that amount of telegraph cable to the bottom of the sea. There was a prophecy long ago that the earth was to be girdled round in forty minutes. Why, we have got as much submarine telegraph cable as will go round the world five times, and we can send a message round the world in twenty minutes at the present moment. You ask me where does all this submarine telegraphy extend, and I reply in those beautiful lines of the poet :--

$$
\begin{aligned}
& \text { "Far as the breeze can b"ar the billows" fuam, } \\
& \text { Survey our Empire, and behold our home!" }
\end{aligned}
$$

Wherever the British ship goes, or the British flag flies, there we have the submarine telegraph; and at the present moment, while I am speaking to you, human thought is travelling like lightning to every part of the world. The future of that no man can tell. Of the $100,000,000$ words which are now carried by submarine telegraphy, nine-tenths are for commercial purposes. When the history of these fifty years of Her Majesty's glorious reign is written, telegraphy, and more especially submarine telegraphy: will be shown to have done more than anything else to federate the great colonies with the mother country, to spread civilization throughout the world, and to make this great world of ours as near as possible one common country.

Sir William Thomson (who was warmly received) said :-I feel that when the telegraph has been so important a bond for all the nations of the world we ought to go even beyond our fifty years jubilee and think for a moment of the great names from other countries to whom the possibility of the jubilee of the electric telegraph has been due-the great apostles of electric science in France, Coulomb and Ampère,-Ampère, whose work and whose discoveries constitute the foundation of the most important of modern telegraphic and electrical instruments generally; Ampère, whose name has become Anglicized and is invariably used in measuring the currents which produce the electric light. Then Gauss and Weber, who made the first electric telegraph. The telegraph of Gauss and Wcber, and the Munich telegraph of Steinheil, and the Steinheil key, which is the manipulating telegraph key of the present day-those were the elements of telegraphy. We justly rejoice that in England so much was made of the work of those grand pioneers in science. In America the race of practical work commenced almost simultaneously with our own in the splendid telegraph of Morse. In speaking of the telegraph we almost forget time and space, and I must go back to the previous work of Henry, who anticipated in some points so ne of the finest discoveries of Faraday, and laid a large part of the theory of current induction, which is at the very root of some of the most splendid realizations of modern electric science, not merely for the electric telegraph, but for electric lighting. By the work of $1857-$ a few years before the half of the jubilee-the two brothers, Edward and Charles Bright, and Whitehouse, those three men, with Mr. Cyrus
Field, reduced to practice that brilliant dream of Cyrus Field to connect England and America by means of submarine telegraphy. Then there were the brothers Werner and William Siemens working in the same direction, and the great navigator Moriarty, who was out in the Agamemnon in I857, and navigated the Agamemnon in I868, and was on the Great Eastern as navigator with Sir James Anderson. In 1865 he picked up the cable where it was broken, and in 1866 , coming back a year after to the same place, hit upon it just a quarter of a mile away, by his splendid navigational powers. Canning and Clifford were also engaged in the work; then there were Varley and Jenkin (who was my special partner) with both of whom I worked for many years. I alone am here to speak for the three. Willoughby Smith, who did such fine work in 1865-66 in testing the cable, applying the newest developments of science, many of them his own inventions, to do what had never been done before, to test a submarine cable with the delicacy that was necessary under circumstances so peculiar, so utterly new. I am exceedingly sorry he is not with us this evening. But I can never forget that we scientists alone could not have done what has been done. To two men, I believe, is due the existence of the 1865 cable, and all the consequences that followed from the I 865-66 cable-John Pender and Cyrus Field. But I must remember that there are other things besides ocean telegraphs. You have told us how splendidly the land telegraphs are worked; you have pointed out how admirably under the influence of the Government system, the application of science to telegraphy has been developed. I think you may feel proud, sir, in knowing that under Government management within these last seventeen years the applications of science to telegraphy have not stood still, but, on the contrary, have been pushed forward with every possible energy and with the most marvellous success. You have told us that the rate of working between Dublin and London has reached 462 words per minute, I think we may say 500 words per minute, and that is ten times what it was ten years ago. That is something for a Government department to be proud of, and for a Government I must say there is some little political importance in the fact that Dublin can now communicate its requests, its complaints, and its gratitudes, to London at the rate of 500 words per minute. It seems to me an ample demonstration of the utter scientific absurdity of any sentimental need for separate Parliaments in Ireland. I should have failed in my duty in speaking for science if $I$ had omitted to point out this, which seems to me a great contribution of science to the political welfare of the world.

Sir Lyon Playfair, M. P., proposed "The Scientific Societies." The scientific Societies, he pointed out, did not profess invention; they professed to lay down the laws of science and to advance natural knowledge. Men who had contributed to the advancement of natural knowledge, like Oersted and Ampère, were as much discoverers of the electric telegraph as if they had themselves actually aided in the invention. The duty of the scientific Societies was to cultivate the tree of knowledge. A great invention never came, as Minerva did, panoplied in complete armour from the brain of Jupiter. But even the brain of Jupiter could not produce this wonderful product of evolution until he had swallowed her mother, Metis, while in the first month of gestation. Our great inventors swallowed science, the mother of invention, and then produced their progeny, always, however, in a state of infancy. The steam-engine, which had done so much for human progress, has had so many inventors that a Court of law, reviewing the steps of invention, came to a solemn decision that Watt had done nothing for the improvement of the steam-engine. Scientific Societies, looking to the advancement of science for its own sake, laid the surest foundations for industrial applications. Oersted and Faraday were as true discoverers of the electric telegraph as Wheatstone, Cooke, or Morse. It was not the annihilation of space and time which was the most wonderful result of the telegraph, but it was the profound change which it had produced in our systems of government and of commerce. Who at its introduction would have supposed that the whole system of commerce would have been transformed by it, that capital would have to change the channels of its usefulness, and that the system of exchanges would undergo such profound alterations? If telegraphy had one lesson which we should lay to heart it was this-that science should be studied for the sake of knowledge, because discoveries in natural knowledge led inevitably to industrial inventions. We should, in regard to all discoveries, however unimportant they seemed, do everything in our power to pro- 
mote their growth, and the growth of natural knowledge throughout the world.

Prof. Stokes said :- Scientific men know well how fascinating is the pursuit of science. Some have even gone so far as to consider that it would be polluted, if I may so speak, by being applied practically. An eminent foreign mathematician delighted in the theory of numbers because one could not conceive that it could have any practical application. An eminent English mathematician $l$ heard express a somewhat similar sentiment. All honour be to those who are so immersed, if I may so speak, in abstract science, that they disregard and even dislike its application. They pursue science with all the more zest, they pursue it in directions which possibly otherwise might not have been followed out, and possibly in the end their own investigations may admit of applications which they never dreamt of, But for my own part my tastes do not quite lie in that direction. I like to see science connected with applications thereof, no matter to what purpose. Now, when we apply abstract science to physical subjects, we are not only enabled to investigate natural phenomena in a manner which could not otherwise be done, but the study reacts on the most abstract parts of science, and enables us sometimes to see, as if it were by intuition, truths of an abstract nature, such as, for example, propositions in pure mathematics, which we perhaps should never have arrived at if we had not viewed them through the spectacles, so to speak, of their physical application. But this is not all. When science comes to be applied to the wants of life, scientific men are placed by the practical man in the condition of making experiments which oftentimes would otherwise be impossible. When science comes to be applied to commercial purposes, it then becomes possible to construct instruments on a scale the expensiveness of which would have been utterly prohibitory to the purely scientific man. But when these instruments are constructed, it may be, for commercial purposes, the scientific man on his part is able by the favour of those who have constructed them, or of those for whom they have been constructed, to make experiments with them which oftentimes are of great interest from a purely scientific point of view.

Dr. Gladstone, responding on behalf of the "Royal Institution, said :-At the Institution there were not merely memories binding them to all those who had passed away, but they had also many relics. They preserved the log-books of Davy, Faraday, and others, and not only that, but there a great number of pieces of wire, sealing-wax, and card, all damaged, and many other things which Faraday especially used to delight to work with and to carry out in the first experiments which were suggested by the ideas that were working in his brain, and these were preserved as germs of some of their great discoveries. And here he wanted to point out one of those germs connected with telegraphy. Those relics preserved at the Royal Institution were only worth originally a few pence or shillings. How different the monster wealth which had now become the capital of those great enterprises! As far as the Royal Institution was concerned, its connexion with the electric telegraph was to a certain extent not direct, and yet it was very real. Sir Humphry Davy worked there of course largely on galvanic electricity, but he belonged to the pre-telegraphic era. Faraday himself commenced to work early on these matters, and continued to try and image in his own mind what was taking place in these phenomena. It was an important point with him that the glories of science should conduce to the benefit of man. They knew his influence with Sir Charles Wheatstone was very great, and he got him into the dark chambers at the Royal Institution and talked to him about his investigations, and in the theatre brought before him some of those experiments which were afterwards performed with so nuch success in public. In one way and another Faraday had to do with the industrial applications of electricity, as well as with scientific discovery. They had the combination of the purely scientific man with the practical man, and then the two going together with slow, careful, conscientious investigation, followed by the energetic carrying out of the discovery in a form which benefited mankind.

Mr. Shaw-Lefevre, M.P., in proposing the " Societies representing Applied Science," said :- -When I was a boy, at Eton, I recollect well the extension of the telegraph from London to Slough, and an incident of which you are all aware, the arrest of Tawell, which I believe brought the telegraph more into notice than anything else at that time. It might have been expected that the authorities of Eton, seeing a great invention of this kind brought to their door, might have been desirous of explaining it to the boys of the school, and might have been drawn out of their deep slumber of ages and done something for the scientific education of the boys then at Eton. But no thought of the kind ever entered into their minds, and the only notice taken of it at the time was that they set it as the subject for Greek verses. I and all the boys of my class commenced racking our brains to write some Greek iambics upon a subject of which we knew nothing, and to bring it into connexion with the mythology of the ancients, of which we knew a good deal. I refer to this for the purpose of showing you how little scienee was promoted then at our public schools. I am glad to say that things have been changed since then, but much has to be done in this direction, and there cannot be a doubt that if this country is to hold its own in the great industrial competition it must give a greater place to science in our schools, and equalize the endowments between the classical and scientific studies; and it is only by doing that I am persuaded that we can hold our own. Mr. Bruce, President of the Institute of Civil Engineers, and Mr. Latimer Clark, past President of the Society of 'Telegraph Engineers, replied; and the latter, after alluding to the work done by the brothers Brett in submarine telegraphy, said :I feel that we, as the representatives of applied science, have been somewhat neglected by the world. I feel that the politicians, some of whom have honoured us by coming here this evening, have very much neglected us. I don't allude to honours, for we shall be very well content with the position of things in that regard; but $I$ feel that they have robbed us of much of our credit for the fact that the great effects of the jubilee which we are now assembled to commemorate have been due to the agency of the applied sciences. I do feel that politicians have been permitted to claim for themselves the credit for the wondrous benefits civilization has received from the efforts of applied science. We hear that so many shillings have been taken off a quarter of wheat, we hear that all the prosperity of the country has been due to free trade, but I say it is not so; I say they have robbed us of our honours in saying that ; I say as guild and craft we ought to proclaim loudly to the world that to our efforts most of all the prosperity of the last fifty years has been due. The population of this great city and of this country when it eats its breakfast to-morrow morning will be consuming food a very large proportion of which has been brought to this country by means of applied science. It is that which has given us our prosperity. They have not taken 5 s. or Ios. a quarter off wheat and corn and eatables, but they have taken off 60 s., 80 s, and Ioos. Wheat will be brought to-morrow from places from which it could not have been brought fifty years ago for ten times what it now costs. As a guild and craft we ought to proclaim loudly that the benefits which we have conferred are the real cause of the prosperity of the great Victorian era which we meet here to celebrate.

The Earl of Onslow having proposed the health of the Chairman in a suitable address, and the Chairman having responded, the proceedings terminated.

The Postmaster-General, during the evening, despatched the following telegram to Sir Henry Ponsonby, at Osborne :--"A large dinner-party celebrating the jubilee of the electric telegraph, remember with gratitude and pride that all the progress has taken place in the happy and proiperous reign of $\mathrm{Her}$ Majesty and under her fostering care."

To this the following reply was received:- "The Queen thanks you for your telegram. It gives Her Majesty much pleasure to reflect on the improvements which have been made in Wheatstone's great invention, which was first practically tested in her reign."

\section{THE CASE FOR A LONDON TEACHING UNIVERSITY.}

THE questions connected with the proposal for the establish. ment of a Teaching University in London were discussed in a speech delivered by Sir George Young at the distribution of prizes in the Medical Faculty of University College, London, on June I, and in a speech delivered by Dr. J. E. Erichsen at the distribution of prizes in the Faculties of Arts and Laws and of Science, at the same institution on June 30. As the case for a London Teaching University was stated by these two eminent authorities, we reprint part of what they had to say on the subject from the point of view of University and King's Colleges. 